\title{
State and Empire in Early Mesopotamia
}

\section{Wang Xianhua}

Sichuan University

\begin{abstract}
Early Mesopotamia in practical use refers to ancient Mesopotamia from the Late Uruk Period to the Ur III Period or the Old Babylonian Period and geographically it includes the watersheds of the Euphrates, Tigris, and Karun Rivers, now divided between Iran, Iraq, Syria, and Turkey (Pournelle 2013; cf. Sherratt 2004; Wright and Johnson 1975). Regarded as one of the few regions in the world that saw civilization, early Mesopotamia has been featuring heavy in discussions of the important 'firsts', the most significant of which would be the emergence of the primary state (Childe 1952; Trigger 2003; Wittfogel 1957). In our division of academic labour, the emergence of the primary state is mostly a topic for the archaeologists and anthropologists, while the traditional historian seldom gets his hands dirty in such theoretical issues. In light of recent rethinkings of fundamental assumptions in modern historiography (Smail 2005; Smail and Shryock 2013), however, it becomes urgent to look for an integrated view of history from its rightful beginning. The following is one attempt as such at the dynamic emergence and the characteristics of the earliest state societies in early Mesopotamia with special attention to the integration of theoretical discussions and insights from philological research (cf. Forest 2005; Postgate 1994a; Stein 2005).
\end{abstract}

\section{INTRODUCTORY NOTES}

In discussions of the earliest state societies in the ancient Near East early Mesopotamia is often spoken of without further temporal differentiation, though the focal time period is usually the Middle to Late Uruk Periods when the earliest primary state is supposed to have taken its place (Postgate 1994a; cf. Richardson 2012). In philological circles, when coming to the question of the earliest political formation in early Mesopotamia, Jacobsen's Kiengir League theory (Jacobsen 1957; Pomponio et al. 1994; Postgate 1994b; Steible and Social Evolution \& History, Vol. 18 No. 1, March 2019 195-216 
Yildiz 1993; Steinkeller 2002), Gelb's Kiš Civilization proposal (Gelb 1981; 1992; Steinkeller 1993), Deimel's Tempelstadt model (Deimel 1931; Foster 1981; Schrakamp 2013), and Diaknoff's Early Antiquity framework (Diakonoff $1974 ; 1991 ; 1999$ ) are among the most frequently discussed. When they do refer to archaeological literature, prominence is given to a selection of authors such as Adams and others' surveys (Adams 1966; 1981; 2008; 2012; Adams and Nissen 1972), Algaze's World System theory (Algaze 1989; 1993; 2013; Stein 1999), Wright's Primary State model (Wright 1977; Wright and Johnson 1975), and Yoffee's engagement with the Archaic State (Yoffee 2005).

It has been pointed out that formal theorization does not seem to be informative enough to philologists than to archaeologists (cf. Yoffee 2005: 7-8). Though this may be more true in the Englishspeaking world where the division of labour is more pronounced than in the Marxist tradition which is inclined to address grander questions (Diakonoff 1999; Foster 2005; Liverani 1998). This gap becomes more lamentable see that, blessed with the rich discoveries of the archaic cuneiform texts which as primary sources from the time when the primary state emerged, philologists ought to contribute more to the discussion on its coming about (Charvát 2002; Englund 2007; 2009; Johnson 2014). This said, however, for the study of the emergence of the primary state, the ongoing decipherment of the archaic cuneiform script, despite great progresses made in the last decades (Englund 1998; Englund and Damerov 2000; Nissen et al. 1993), plays a double role. On the one hand, potentially most important information can be gleaned from philological studies of the archaic texts (Englund 2007; 2009); on the other hand, uncertainties in the interpretation and contextualization of these texts undoubtedly hindered their potential value for related discussions (Postgate 2005).

In this contribution with an explicit purpose of engaging with theoretical discussions of the primary state in the context of early Mesopotamia, the first section will focus on current models of the emergence of the primary state in early Mesopotamia, primarily by archaeologists and anthropologists. In a way early Mesopotamia has unduely been lagging behind the theoretical trends in recent decades, perhaps to do with the fact that archaeological works in Iraq have been halted by contemporary political situation (Ur 2012). On the other side, archaeologists working in Mesopotamia also made remarkable contributions by readdressing theoretical problematics, restudying evidence available from earlier times, and integrating insights from fieldworks elsewhere (Forest 2005; Ur 2014; Wright 2006; Yoffee 2005). 
After the literature review and with the particular audience of this contribution in sight, the next section instead proposes to borrow methodology from historical sociology, especially the analysis of power networks as promoted by Michael Mann (1986), for a more coherent understanding of the emergence of the primary state as an integrated part of human history, despite the fact that as another field rich in formal theorization historical sociology has rarely been mentioned in discussions of the emergence of the primary state. In fact, network analysis has been gaining influence over the past decades. It is only that it was done often without explicit reference to methodology in historical sociology (Algaze 2013; Renfrew and Cherry 1986; Smith 2003; Wright 2006). In the form of diachronic description of the changing power networks at work in early Mesopotamia, this section also provides a general outline of the emergence of the primary state based on recent research.

The purposeful application of historical sociological methodology, particularly that of network analysis to the search for the emergence of the primary state results in surprising conclusions as it questions the evolutionary scheme particularly that from state to empire (Dillehay 2014; Yoffee 2005). Accordingly, the third section of the main text attempts to argue that the emergence of the primary state may have been better understood in the context of empire formation, by reanalyzing critical evidence both historical and theoretical. From this renewed understanding, the state as commonly named will have to be conceptually seen as a form of empire rather than vice versa. At least in the context of early Mesopotamia, it can be argued that historically empire preceded the fiscal state. At the same time, the so-called city-states of the Early Dynastic Period, again contrary to common understanding, are difficult to be taken as states despite their nomenclature (Ur 2014). It is believed that for the study of the ancient world in general and the emergence of the primary state in particular, 'bringing the empire back in' will provide a more powerful thread for a history with its rightful beginning (Colomer 2008; Garfinkle 2012; Mann 1986).

\section{MODELS FOR THE EMERGENCE OF THE STATE}

In a review of the contribution of anthropology to the question of the emergence and survival of complex states and civilizations in the ancient Near East up to the 1970s, the anthropologist Elman Service recognized two major theoretical approaches to the issue, integration theory and conflict theory (Forest 2005; Service 1978). From the perspective of integration theory, state institutions emerge as a more complex level of social and economic integration in response to new challenges. 
The state thus emerges as a mechanism through which its citizens adapt to their social and physical environment. The effectiveness or ineffectiveness of the state's institutions and its leaders in performing those adaptive tasks would determine whether the state survives. Wittfogel's hydraulic model represents this type of theories as it directly links the emergence of the state with the necessity for irrigation, though it is no longer favorable in light of serious criticisms (Fernea 1970; Harrower 2009; Pournelle 2013; Rost 2011; Wittfogel 1957).

Integration theory is derived from functionalism or structural functionalism as well as general systems theory and cultural ecology (Dickson 2013; Forest 2005). The particular challenges the citizens needed to adapt therefore came to be the distinctive parts in the explanations for the emergence of the primary state. The influence of Wittfogel's simplistic model fading away, it is perhaps still valid to speak of most of the contemporary elaborated explanations of the rise of the primary state in early Mesopotamia as 'fully and effectively utilizing Integration theory in generating conclusions' (Dickson 2013). In such explanations, early Mesopotamian states are by and large hypothesized as interconnected adaptive systems, and little attention is paid to the question that these polities were likely riven with deep internal social conflict and competition over scarce resources. By focusing on the integrative or functional role played by state organizations, scholars of early Mesopotamia tend to neglect to test the alternative hypotheses drawn from conflict theory about the nature of these early states (Dickson 2013; Ur 2014: 5-6).

In early Mesopotamian studies, the attribution of the rise of the primary state to a combination of population growth and the replacement of former marshlands in southern Mesopotamia by lands suitable for agriculture remains widely circulated, as by one who had been an active part of both archaeological field work and textual research (Nissen 1986; 1993; Pournelle 2007). The more theoretically oriented archaeologist and a colleague of Nissen's, Robert Adams with his comparative perspective and unparalleled experiences in archaeological surveys stressed social stratification as the immediate lead to the state along the shift away from kinship to a society based on class and residence. It is believed that along the shift new forms of 'disembedded' and functionally specific institutions emerged (Adams 1966: 79$84 ; 1984 ; 2012)$. It is obvious that for Adams population growth evident in the Uruk area remains as the starting point for an answer to the question.

In spite of the criticisms of their theoretical orientations and of the realization that new synthesis is needed for the emergence of the 
primary state in early Mesopotamia, the time is perhaps not ripen. The more recent presentation of the issue provides a more nuanced way to regard population growth as the primary mover towards state in considering the decline of kinship in early Mesopotamia to have been associated with the monopolization of the interface between man and the gods by the elites so to allow for extra-familial interactions (Forest 1996; 2005: 201-204; Ur 2014). In recent decades, however, when great progresses have been made in archaeological research of greater Mesopotamia, but the problem of the emergence of the primary state has not been always a central concern (Algaze 2013; Ur 2010b; Yoffee 2005).

The most focused discussion on the origins of state in early Mesopotamia was by Henry Wright and his colleagues, who opted to look at the primary state from the perspective of information control. In its original formulation, this approach saw managerial advantage as pivotal for the success of the state, which is defined accordingly (Wright 1977; Wright and Johnson 1975). In Wright and Johnson's case study, multi-tiered settlement hierarchies signified the development of administrative hierarchies, and the information processing institutions are depicted as efficient and centralizing means for overseeing the production and distribution of luxury and staple products. The wide distribution of the famous beveled rim bowls, for instance, is taken to signify central institutions distributed cereal products to dependent workers, thus revealing the state's labor administration (Wright and Johnson 1975).

By stressing the importance of information flow this approach opens new possibilities as the system of cuneiform writing was under development in the region at this time (Johnson 2014; SchmandtBesserat 1996; Woods 2010). The definition of state apparatus as a system of information control, however, encounters difficulties if challenged by differing interpretations of factual evidence (Goulder 2010; Potts 2009). In addition, one problem inherent in this approach is the unquestioned equation of the emergence of primary state with the appearance of state apparatus whose definition is rather artificial (Wright 1984; Yoffee 2005: 20).

Wright later reopened the issue of the emergence of the primary state through case studies other than early Mesopotamia (Wright $2005 ; 2006)$. In the case of Madagascar, for instance, Wright noticed that the attempts to build states took place in contexts of intense conflicts. And there were many successes and failures before enduring states emerged while the specific context of successful state formation was one of closely spaced, intensely competing centers. Based on this 
realization Wright retheorized the emergence of the primary state as resulting from processes of 'political experiment' (Wright 2006). The emergence of the primary state presumes earlier forms of social inequality and is by no means a steady process (Marcus 1998; Redmond and Spencer 2012). For Wright, nevertheless, the state is the result of goal-directed decision making of which the understandings of the past are an inherent part. The important task for the researcher is to 'precisely characterize the organization of successive efforts to build successful political or social formations, and the factors that led to failures and successes' (Wright 2006: 316).

It may be pointed out here that integration and conflict theories for the emergence of the primary state are not necessarily exclusive to each other. In classical conflict theory, the presumption is that profound inequalities in power exist, both between social systems and within, and competition over scarce resources often leads to violence and warfare which is the prime mover to the emergence of states (Carneiro 1970; Mann 1986; Tilly 1985). The state emerges out of the struggles and persists if its leader can maintain a stable or dynamic equilibrium between the various conflicting parties (Adams 2008; Dickson 2013; Tilly 1985). Wright's reformulation of the processes of state formation may be considered in dialogue with, if not integrating conflict theories of state formation in that it further specifies the mechanisms that expressed such conflicts (Wright 1984; 2006; 2007). In addition, it may be mentioned at this juncture that, Algaze's longdistance trade model is also potentially compatible with conflict theory for the emergence of the primary state in early Mesopotamia, as war breaks out easily in contexts involving economic interdependence (Algaze 2013; Copeland 2014).

\section{NETWORKS OF POWER IN EARLY MESOPOTAMIA}

'To this point we have talked about states in isolation, but they, like chiefdoms, usually exist in networks of states. Among simple states these networks seem to be regulated by competition and alliance, as was briefly noted for chiefdoms. A difference is that developing state networks are periodically centralized into a single political unit incorporating most previously existing polities. Such polities, which may be termed "empires", have many interesting features, but they are not of direct concern in this review' (Wright 1977: 385). In spite of his uses of terminology that bear marks of time (Cioffi-Revilla 2005; 2014), Wright already realized that the primary state cannot exist in isolation. He called for 'more sophisticated theoretical constructs and more research, both in-depth research on Early Uruk systems and 
broader research to bring understanding of the different developing societies of the interregional network to an equivalent level throughout greater Mesopotamia' (Wright 1977: 389).

In addition to advances in field archaeology (Cooper 2006; McMahon 2009; Ur 2010a; 2010b), the most telling new theoretical trend recently has been the stress on the regional level, on polycentricity and networks (Algaze 2013; Smith 2003; Stein 2005; Wright 2005). And at the core of this theoretical switch regarding the problem of the emergence of the primary state lies a different approach to social power. 'Ancient states generally have been associated with an image of power as a 'thing' one that was concentrated in the beginnings of a differentiated administrative apparatus and the top echelons of the ruling regime, from which it spread outward across distant lands, and downward into the lives of people' (Dillehay 2014: 32). But political power in particular, is not anything readily to be analyzed for its distribution and allotment. It can only be approached by looking at the organizational or institutional means of attaining human goals in specific contexts, to use Michael Mann's terminology. For Mann (1986: 6-9), societies are constituted of multiple overlapping and intersecting socio-spatial networks of power most relevantly ideological, economic, military, and political (Lieven 2000: 447; North et al. 2009: 2). It is only in terms of these socio-spatial networks, the sources of social power in his terminology, the society under concern may be accounted for.

Mann stresses the primacy of these socio-spatial networks not for the strength of human desires for ideological, economic, military, or political satisfaction respectively but for the particular organizational means each of such networks possesses to attain human goals. The analysis of the organizational reaches and the 'promiscuity' of the networks is the major task with social 'caging' as a particularly significant element in the dynamics of the emergence of the primary state (Carneiro 1970; Mann 1986; 2006). In this sense the explanation for the emergence of the state becomes the explanation for the success of it as a particular form or power, that of the political (North et al. 2009: 2). This means the dynamics of the emergence of the state in early Mesopotamia can only be sought in terms of the emergent social-political networks. Indeed, both integration theories and conflict theories for the rise of the primary state can be further understood as varied approaches to the promiscuity of power networks (Dickson 2013: 312-314).

Both the Ubaid and the Uruk Periods in early Mesopotamia are characterized by cultural exchanges forming large networks. It has been however noticed the expansions are to be differentiated as they 
had different dynamic and mode(s) of socioeconomic organization. The Ubaid expansion took place largely through 'the peaceful spread of an ideology, leading to the formation of numerous new indigenous identities that appropriated and transformed superficial elements of 'Ubaid material culture' (Stein and Özbal 2007: 329). The Uruk expansion, in contrast, was 'an actual colonial phenomenon, involving the founding of Mesopotamian trading enclaves among preexisting local polities and emulation by local groups in the so-called peripheral areas' (Algaze 2013; Stein and Özbal 2007: 329-330). It is observed that changes in residential buildings and in burial practices of the Ubaid Period reflected hierarchization of societies was certainly underway (Forest 2005). In the Uruk Period, hierarchy came to be more pronounced and some hereditary elite settled into place, with one individual of higher rank named as leader or king. The earliest cities are founded, and the alluvial plain was divided into a series of principalities with mainly urban populations (Forest 2005: 190-191).

It is generally agreed that the earliest state began to take its form in the context of this so-called Uruk expansion (Algaze 2013; Stein 2014). At least by the end of the Uruk Period, scholars assume that the state was in place in southern Mesopotamia and most likely the focal city was Uruk (Englund 1998; Johnson 1973; Liverani 1998; van de Mieroop 2007: 23-27). The flow of goods require new techniques of management such as cylinder seals and other record keeping devices such as writing. The 5,400 tablets recovered from Uruk are primarily concerned with economic matters and record great quantities of sheep, agricultural products, beer, and land. Despite the fact that they are more likely the economic records of temples, the use of proto-cuneiforms has been considered to be testimonies of state administration (Englund 2009; Forest 2005; Liverani 1998; Wang 2014). In order to ensure the cohesion of society, an ideology was formulated to exalt kingship and temples built for the gods (Forest 2005: 193-195; Liverani 1998: 28). In light of the phenomenal discoveries of temples, cylinder seals with iconography of the 'priest-king', the earliest cuneiform tablets, artifacts of specialized mass production, and even hints of class struggle (Englund 2009), it is difficult to deny that an advanced form of social formation was there in Late Uruk Mesopotamia. McMahon's (2009) recent discoveries of the Tell Brak archaic sealings seem to signify the real presence of the 'priest-king' as far north as in Tell Brak.

On the other hand, strictly speaking evidence is insufficient to measure if it agrees with our definition of a state that stresses on 'specialized, differentiated institutions with authoritative decision making, 
capacity to collect taxes as government revenue, and reliable control over territory and its resources' (Cioffi-Revilla 2014: 199). It is also a tremendously difficult task to trace the processes of the political experiments behind it (Wright 2006). The question whether these cities with kings, as modern scholars would like to understand them, are to be considered proper states, has to remain (Forest 2005; Ur 2014). What is certain about these Mesopotamian urban centers is only that they existed in networks of power which in all likelihood continued to play into the Early Dynastic Period, though war became then more frequently attested (Hamblin 2006; Matthews 1993; Steinkeller 2002). Although evidence is far from plenty for the period of Early Dynastic II in early Mesopotamia, there are reasons to believe that a tumultuous struggle for hegemony between regional centers including Kiš and Uruk was undergoing (Gelb 1981; 1992; Steinkeller 1993). Later in Early Dynastic III times the competition seemed to be largely between Lagaš, Ur and Kiš (Cooper 1983; Frayne 2009; Marchesi 2015). It culminated with the establishment of a regional kingdom in southern Mesopotamia headed by Lugalzagesi, erstwhile governor of Umma and later king of Uruk (Frayne 2009; Wang 2011).

It has long been believed that the cities were dominated by temple-based states in which the gods owned all of the land and its products, but this Tempelstadt thesis has been seriously challenged by subsequent research (Deimel 1931; Schrakamp 2013). For some, these cities of Early Dynastic Mesopotamia are localized power centers after the collapse of the Uruk system which may even be termed an empire (Westenholz 2002). For others, the so-called city-states are qualitatively not states at all but constellations of households including the temples and palaces (Ur 2012; 2014). There may have existed a shared elite culture that distinguished the temple and the palace elites, as Sallaberger (2013) observed (cf. van de Mieroop 2002), but interpreting palatial culture in terms of the state still poses definitional questions. The Royal Cemetery of Ur the impressive palaces at Kiš were testimonies of royal power but not qualifying evidence for real states (Mackay 1925; Zettler and Horne 1998). It can only be said that the struggle for hegemony may have paved the way for the outcome that was the Sargonic empire, or in fact, it was the process of political experiment that leads to the emergence of the primary state (Frayne 2009; Steinkeller 2013). The interesting debate whether the Sargonids were true creators of a state or were entitled to an even more advanced stage of political evolution, that of an empire, will continue (CioffiRevilla 2014: 122; Foster 2011). 


\section{STATE AND EMPIRE IN EARLY MESOPOTAMIA}

For Forest, it was when the city-states in the Early Dynastic Period became too structured to give rise peacefully to any further development, the state became an ultimate means of finding a solution to evolutionary mechanisms that could not play out further. The Sargonic Empire, in this view, is the summit of the processes and the emergent political network at the end, in which state apparatus is combined with ideological centralization as diagnostic of the primary state (Forest 2005: 198-199; Mann 1986; Steinkeller 1993; Westenholz 1999; Wright 2006). The processes of 'political experiments' that led to the formation of the full-fledged state seem to have started by the Uruk Period in a context of regional competition along the creation of large ritual buildings (Liverani 1998; Wright 2006). The emergence of the primary state, in this scenario, paradoxically becomes equivalent to the emergence of the first empire as the Sargonids were to claim. This paradox drives back the difficult question of whether Uruk of the Late Uruk Period already represented a state ( $c f$. Yoffee 2005: 30, Figure 2.1-2).

The understanding of the Uruk Expansion has been significantly improved recently and it may be possible to elaborate on its consequences for discussions of the emergence of the primary state. For long, the Uruk Expansion had been understood as lasting only about a century and half during the later phase of the Uruk Period. However, based on new research, '[i]t now seems clear that the expansion took place over a very long period - minimally 500 years, maximally $700-$ in a series of movements, and in various directions' (Porter 2012: 8384). In her latest synthetical study of Uruk Mesopotamia, Porter divided the history of Uruk and Uruk-related settlements into three basic groups: 'Early (3700/3600-3400 BCE), consisting of Susa, Abu Salabikh, Qraya, Tell Brak, and Sheikh Hassan; middle (3400-3300/3250 BCE), in which Hacinebi, Zeytinli Bahçe, Kosak Shamali, and Godin Tepe are added to the preceding group; and late (3250-3000 BCE), consisting of Habuba Kabira South and Jebel Aruda (Qraya has disappeared), Hassek Höyük, Arslantepe (Hacinebi has disappeared) and Godin Tepe'. Porter (2012: 91-92) points out that, 'while the overall pattern of expansion seems like a gradual rise, retraction, and collapse, the small shifts within this mapping should be given due consideration'. It is within this spotted process, the presumed emergence of the primary state and its defining characteristics have to be located (Liverani 1998; Postgate 2003).

The economic success of the South in the trading economy merits special attention (cf. Forest 2005: 187; Pollock 2001). In a series of 
studies Algaze had been repeatedly stressing external factors, especially long distance trade, for what he named the 'Sumerian Takeoff' (Algaze 1989; 1993; 2008; 2013; Englund 2007; Forest 2005). Inspired by Goldstone (2002) and others, Algaze (2013) took Uruk as an 'efflorescence' inspired by long distance trade. In his perception, the length of the initial phase of the Smithian Growth lasted for the better part of the $4^{\text {th }}$ millennium in the southern Mesopotamian case but was much shorter in other areas of southwest Asia where early exchange-based specialization and urbanism also flourished. In the Upper Khabur the initial efflorescence led to a long period of stagnation marked by the disintegration of the indigenous urban tradition of the area for a millennium. In southern Mesopotamia, however, the Jemdet Nasr retrenchment gave way to another phase of Smithian Growth barely two centuries or so after the end of the Uruk efflorescence (Algaze 2008: 14-24).

In this impressive economic phenomenon, it is probable that Uruk held a distinctive place within a regional network of competing cities, as archaeologists believe the Nippur-Adab region has to be distinguished from the Uruk city region (cf. Pollock 2001; Postgate 1986). However, that Uruk was a state could not explain the most impressive economic success of the South in a longer time span (Liverani 1998). In terms of Algaze's Smithian Growth, political or other factors specific to the south might have contributed to the second wave of its economic success in the Jemdet Nasr Period, but the more substantial and lasting first wave of its success remains mysterious (Algaze 2013). I have suggested that the regional stateless economic infrastructures of southern Mesopotamia as a whole, particularly the temples, have been responsible for the phenomenal growth (cf. Forest 2005: 193-195; Lin 2012; Wang 2015).

The dynamics of the Uruk expansion and the role the city of Uruk played in it will continue to be debated (Algaze 2013; Pournelle 2007). But from what can be grasped, it would be safer to say that Uruk Phenomenon was mainly one of economic rather than of political network. Anthropologists have pointed out that the standardization of artifacts in pre-state societies is more for economic purposes than political, thus there can be no evidence for the presence of the state (Dillehay 2014: 31-54; Goulder 2010; Johnson 1973; Potts 2009). The distinctive importance of Uruk notwithstanding the appearance of the earliest cuneiform writing is neither sufficient evidence for the existence of a state administration (Ur 2012: 539), though federal activities centered on the cult of the city could have been operating (Steinkeller 2002). In addition, if to borrow from James Scott's term, 
the emergence of the primary state may be better described as an 'evolution of simplicity' rather of complexity (Dillehay 2014: 42; Scott 1998; Yoffee 2001), the Uruk of the Uruk Expansion would have been too complex to be a state, as the contemporary use of different mathematical systems may hint at (Høyrup 1991).

In agreement with Forest, therefore, the Sargonic Empire was the end result of the dynamic process and was the primary state in which a warrior stratum came into being, after Lugalzagesi had already invented the most powerful simplifying device that was an orthodox view of history (Dillehay 2014: 48-49; Forest 2005). In light of this rather counter intuitive conclusion that saw the Sargonic Empire as the primary state taking place in early Mesopotamia and the preceding Uruk in the Late Uruk Period as only an economic and ritual center, it is necessary to involve the relationship of state and empire and not only for the clarification of terminological use. Indeed, it has been assumed that empire as a political form has to build upon preexisting state structures (Cioffi-Revilla 2014: 122). On the other side, it is claimed that now we need to "recognize that such distinctions as "empires" and "states" are artificial, imposed upon what is clear only in hindsight, and that the distinction may have not made much sense to anyone even as late as the nineteenth century' (Centeno and Enriquez 2011: 97).

There is no equivalent word to the concept of state, or that of empire, that exists in Sumerian or Akkadian, the major languages used in ancient Mesopotamia for millennia (Barjamovic 2012; Ur 2014: 7). Seeing this, Jason Ur (2014: 5) argued to understand the rise of cities and the state in Mesopotamia centered on the concept of the household, which according to him follows an emic approach (Schloen 2001; Seri 2005). For him, though recent approaches attempted to make later developments contingent on earlier political or economic events, the processes are generalized rather than specifically tied to local history (Algaze 2008; 2013; Wright 2006), as existent models 'tend to disregard emic social understandings and the enduring significance of pre-Uruk structural conditions' (Ur 2014: 5-6). Instead of taking the native terminology of household and kinship as class-based and bureaucratic from the etic perspective, Ur suggests that urbanism in early Mesopotamia had be better understood in the context of the metaphorical extension of the household. "This alternative model calls into question the applicability of terms like "urbanism" and "the state" for early Mesopotamian society' (Ur 2014).

In light of the critiques of political economics when applied to ancient societies by forcing modern concepts backwards (Latour 2009; Polanyi 2001), an emic perspective towards the social formations in 
early Mesopotamia is apparently most welcome. Of course, one may still argue that simply 'through the lens of its third millennium descendant' has similar problems by working from the known to the unknown through historical analogies since household as such may well be the consequences rather than the pretexts of change (Dillehay 2014: 47-49; Ur 2014: 7-8), and taphonomic problems are ever present (Postgate 2005). But the fact is, this emic perspective forces one to reconsider our application of the concepts such as state or empire, and conventional wisdom seems to gain value as interregional networks in early Mesopotamia have been named empires often without distinctions of what particular organizational means were primarily used for human purposes (Steinkeller 2002; Westenholz 2002). Indeed, if the metaphorically extended household tries to reach its goals with certain organizational means, a network of power will quite possibly materialize on the scale of a patrimonial state or an empire (Steinkeller 2004; Ur 2012).

'Empires of domination would be a better description for unstable federations of rulers prostrated under the foot of Sargon and his successors, whose state was the 5,400' (Mann 1986: 145). In this understanding, the state of Sargon was only one form of empire, empire of domination, as an empire as a network of power is more diverse. The city of Uruk in the Late Uruk Period, then, could be accorded as an economic empire with its major difference from the Sargonic case in its lack of an infrastructure typically political and the capability to recourse to military power presumably for fiscal purposes. The earliest primary state in the form of an empire is thus no surprise since its emergence was necessarily 'utopic' or 'telescopic' (Dillehay 2007; 2014), or 'presumptive' to use Richardson's (2012) term, when the other organizational means failed to sustain itself. Empires were natural while the particular form of empire, the state in it was primary an invention as well as the art of politics.

\section{CONCLUDING REMARKS}

To sum up, our discussion of the emergence of the primary state in early Mesopotamia has resulted in a rather unorthodox view of the primary state as a form of empire, or, a particular form of organizational network to achieve human goals, that of the political. By the word political, the basic meaning is civil administration in the sense of fiscal means (Monson and Scheidel 2015). In early Mesopotamia, it was the Sargonids who accomplished this rather unencouraging type of social formation and were thus rightfully the creators of the primary state. The question remains whether the Sargonic way to rule the 
world was an autonomous development or partially inherited from earlier traditions, either from the Sumerian south or the Kišite north (Jacobsen 1976; Mann 1986: 155-156; Steinkeller 1993).

At last, encouraged by the recent trend of social scientifically informed discussions of early Mesopotamian history (Barjamovic 2012; Fleming 2014; Garfinkle 2012; Mann 1986; Richardson 2012; 2015; von Dassow 2012), and in line with this understanding of the emergence of the primary state in early Mesopotamia, a call for the future may be made that we may need to 'bring the empire back in' for a better interpretation of the beginning of state and state politics in the remote ancient world, paraphrasing but fully appreciating Theda Skocpol's appeal three decades ago (Colomer 2008; Skocpol 1985).

\section{REFERENCES}

Adams, R. McC. 1966. The Evolution of Urban Society: Early Mesopotamia and Prehispanic Mexico. New York: Aldine Publishing.

Adams, R. McC. 1981. Heartland of Cities: Surveys of Ancient Settlement and Land Use on the Central Floodplain of the Euphrates. Chicago: University of Chicago Press.

Adams, R. McC. 1984. Mesopotamian Social Evolution: Old Outlooks, New Goals. In Earle, T. (ed.), On the Evolution of Complex Societies. Essays in Honor of Harry Hoijer (pp. 79-129). Malibu: Undena Publications.

Adams, R. McC. 2008. An Interdisciplinary Overview of Mesopotamian City and its Hinterlands. Cuneiform Digital Library Journal 1: 1-23.

Adams, R. McC. 2012. Ancient Mesopotamian Urbanism and Blurred Disciplinary Boundaries. Annual Review of Anthropology 41: 1-20.

Adams, R. McC., and Nissen, H. J. 1972. The Uruk Countryside: The Natural Setting of Urban Societies. Chicago: University of Chicago Press.

Algaze, G. 1989. The Uruk Expansion: Cross-Cultural Exchange in Early Mesopotamian Civilization. Current Anthropology 30 (5): 571-608.

Algaze, G. 1993. The Uruk World System: The Dynamics of Expansion of Early Mesopotamian Civilization. Chicago: University of Chicago Press.

Algaze, G. 2008. Ancient Mesopotamia at the Dawn of Civilization: The Evolution of an Urban Landscape. Chicago: University of Chicago Press.

Algaze, G. 2013. The End of Prehistory and the Uruk Period. In Crawford, H. E. W. (ed.), The Sumerian World (pp. 68-94). London: Routledge.

Barjamovic, G. 2012. Mesopotamian Empires. In Bang, P. F., and Scheidel, W. (eds.), The Oxford Handbook of the State in the Ancient Near East and Mediterranean (pp. 120-160). Oxford: Oxford University Press.

Carneiro, R. L. 1970. A Theory of the Origin of the State. Science 169: 733-738.

Centeno, M. A., and Enriquez, E. 2011. Legacies of Empire? In Hanagan M., and Tilly Ch. (eds.), Contention and Trust in Cities and States (pp. 95-112). New York: Springer. 
Charvát, P. 2002. Mesopotamia before History. London: Routledge.

Childe, V. Gordon 1952. New Light on the Most Ancient East: The Oriental Prelude to European Prehistory. Revised edition. New York: W.W. Norton \& Company.

Cioffi-Revilla, C. 2005. A Canonical Theory of Origins and Development of Social Complexity. The Journal of Mathematical Sociology 29 (2): 133-153.

Cioffi-Revilla, C. 2014. Introduction to Computational Social Science: Principles and Applications. Texts in Computer Science. London: Springer-Verlag.

Colomer, J. M 2008. Bringing the Empire Back In. Journal of Globalization, Competitiveness and Governability 2 (1): 48-58.

Cooper, J. S. 1983. Reconstructing History from Ancient Inscriptions: The LagashUmma Border Conflict. Malibu: Undena Publications.

Cooper, L. 2006. Early Urbanism on the Syrian Euphrates. London: Routledge.

Copeland, D. C. 2014. Economic Interdependence and War. Princeton: Princeton University Press.

Deimel, A. 1931. Sumerische Tempelwirtschaft zur Zeit Urukaginas und seiner Vorganger: Abschluss der Einzelstudien und Zusammenfassung der Hauptresultate. Analecta Orientalia 2. Roma: Pontificio Istituto Biblico.

Diakonoff, I. M. 1974. Structure of Society and State in Early Dynastic Sumer. Los Angeles: Undena Publications.

Diakonoff, I. M. 1999. The Paths of History. Cambridge: Cambridge University Press.

Diakonoff, I. M. (ed.) 1991. Early Antiquity. Chicago: Chicago University Press.

Dickson, D. Bruce 2013. Kingship as Racketeering: The Royal Tombs and Death Pits at Ur, Mesopotamia, Reinterpreted from the Standpoint of Conflict Theory. In Hill, Jane A., Jones, P., and Morales, A. J. (eds.), Experiencing Power, Generating Authority: Cosmos, Politics, and the Ideology of Kingship in Ancient Egypt and Mesopotamia (pp. 311-328). Philadelphia: University of Pennsylvania Press.

Dillehay, T. D. 2007. Monuments, Empires, and Resistance: The Araucanian Polity and Ritual Narratives. Cambridge Studies in Archaeology. Cambridge: Cambridge University Press.

Dillehay, T. D. 2014. The Telescopic Polity: Andean Patriarchy and Materiality. Cham: Springer.

Englund, R. K. 1998. Texts from the Late Uruk Period. In Bauer, J., Englund, R. K., and Krebernik, M. (eds.), Mesopotamien: Späturuk-Zeit und Frühdynastische Zeit (pp. 15-233). Fribourg: Editions Universitaires.

Englund, R. K. 2007. 'An Examination of the Textual' Witnesses to Late Uruk World Systems'. In Gong, Y. and Chen, Y. (eds.), Special Issue of Oriental Studies: A Collection of Papers on Ancient Civilizations of Western Adia, Asia Minor and North Africa (pp. 1-38). Beijing: Jingji Ribao Chubanshe.

Englund, R. K. 2009. Smell of the Cage. Cuneiform Digital Library Journal 2009 (4): $1-27$. 
Englund, R. K., and Damerov, P. 2000. Cuneiform Digital Library Initiative: A Joint Project of the University of California, Los Angeles, the University of Oxford, and the Max Planck Institute for the History of Science, Berlin. Published by Cuneiform Digital Library Initiative. URL: http://cdli.ucla.edu/.

Fernea, R. A. 1970. Shaykh and Effendi: Changing Patterns of Authority among the El Shabana of Southern Iraq. Harvard Middle Eastern Studies 14. Cambridge, MA: Harvard University Press.

Fleming, D. E. 2014. Chasing Down the Mundane: The Near East with Social Historical Interest. Journal of Ancient Near Eastern History 1 (1): 5-15.

Forest, J.-D. 1996. Mésopotamie: l'apparition de l'Etat, VII-e-III-e millénaires. Paris: Méditerranée.

Forest, J.-D. 2005. The State: The Process of State Formation as Seen from Mesopotamia. Susan Pollock and Reinhard Bernbeck. Archaeologies of the Middle East: Critical Perspectives (pp. 184-206). Blackwell Studies in Global Archaeology. Oxford: Blackwell.

Foster, B. R. 1981. A New Look at the Sumerian Temple State. Journal of the Economics and Social History of the Orient 24 (3): 225-241.

Foster, B. R. 2005. Shuruppak and the Sumerian City State. Kogan, L., Koslova, N., Loesov, S. V., and Tishchenko, S. (eds.), Memoriae Igor M. Diakonoff (pp. 71-88). Babel und Bibel 2. Winona Lake: Eisenbrauns.

Foster, B. R. 2011. The Sargonic Period: Two Historiographic Problems. In Barjamovic, G., Dahl, J. L. Koch, U. S., Sommerfeld, W., and Westenholz, Goodnick J. (eds.), Akkade is King: A Collection of Papers by Friends and Colleagues Presented to Aage Westenholz on the Occasion of His 70th Birthday 15th of May 2009 (pp. 127-138). Leiden: Nederlands Instituut voor het Nabije Oosten.

Frayne, D. R. 2009. The Struggle for Hegemony in 'Early Dynastic II' Sumer. The Canadian Society for Mesopotamian Studies Journal 4: 37-75.

Garfinkle, S. J. 2012. Entrepreneurs and Enterprise in Early Mesopotamia: A Study of Three Archives from the Third Dynasty of Ur (2112-2004 B.C.). Cornell University Studies in Assyriology and Sumerology 22. Bethesda: CDL Press.

Gelb, I. J. 1981. Ebla and the Kish Civilization. In Cagni, L. (ed.), La lingua di Ebla: Atti del convegno internazionale (Napoli, 21-23 aprile 1980) (pp. 973). Napoli: Istituto universitario orientale di Napoli.

Gelb, I. J. 1992. Mari and the Kish Civilization. In Young, G. D. (ed.), Mari in Retrospect (pp. 121-202). Winona Lake: Eisenbrauns.

Goldstone, J. 2002. Efflorescences and Economic Growth in World History: Rethinking the 'Rise of the West' and the Industriai Revolution. Journal of World History 13: 323-389.

Goulder, J. 2010. Administrators' Bread: An Experiment-Based Reassessment of the Functional and Cultural Role of Uruk Bevel-Rim Bowl. Antiquity 84: 351-362.

Høyrup, J. 1991. Mathematics and Early State Formation. Reprints 1991 nr. 2. Række: Filosofi og videnskabsteori på Roskilde Universitetscenter. 
Hamblin, W. J. 2006. Warfare in the Ancient Near East to 1600 B.C: Holy Warriors at the Dawn of History. London: Routledge.

Harrower, M. J. 2009. Is the Hydraulic Hypothesis Dead Yet? Irrigation and Social Change in Ancient Yemen. World Archaeology 41 (1): 58-72.

Jacobsen, T. 1957. Early Political Development in Mesopotamia. Zeitschrift für Assyriologie und vorderasiatische Archäologie 52: 91-140.

Jacobsen, T. 1976. The Treasures of Darkness: A History of Mesopotamian Religion. New Haven: Yale University Press.

Johnson, G. A. 1973. Local Exchange and Early State Development in Southwestern Iran. Anthropological Papers 51. Ann Arbor: University of Michigan Museum of Anthropology.

Johnson, J. Cale 2014. Late Uruk Bicameral Orthographies and Their Early Dynastic Rezeptionsgeschichte. Working Paper des SFB 980 No. 2/2014. Berlin: Freie Universität.

Latour, B. 2009. The Science of Passionate Interests: An Introduction to Gabriel Tarde's Economic Anthropology. Chicago: Prickly Paradigm Press.

Lieven, D. 2000. Empire: The Russian Empire and Its Rivals. New Haven: Yale University Press.

Lin, J. Y. 2012. The Quest for Prosperity: How Developing Economies Can Take Off. Princeton: Princeton University Press.

Liverani, M. 1998. Uruk: The First City. London: Equinox.

Mackay, E. 1925. Report on the Excavation of the 'A' Cemetery at Kish, Mesopotamia, Part 1. Anthropology Memoirs I. Chicago: Field Museum of Natural History.

Mann, M. 1986. The Sources of Social Power, I: A History of Power from the Beginning to A.D. 1760. Cambridge: Cambridge University Press.

Mann, M. 2006. The Sources of Social Power Revisited: A Response to Criticism. In Hall, J. A., and Schroeder, R. (eds.), An Anatomy of Power: The Social Theory of Michael Mann (pp. 343-396). Cambridge: Cambridge University Press.

Marchesi, G. 2015. Toward a Chronology of Early Dynastic Rulers in Mesopotamia. In Sallaberger, W., and Schrakamp, I. (eds.), Associated Regional Chronologies for the Ancient Near East and the Eastern Mediterranean: History \& Philology (pp. 139-156). Turnhout: Brepols.

Marcus, J. 1998. The Peaks and Valleys of Ancient States: An Extension of the Dynamic Model. In Feinmann, G. M., and Marcus, J. (eds.), Archaic States (pp. 59-94). Santa Fe: School of American Research Press.

Matthews, R. J. 1993. Cities, Seals and Writing: Archaic Seal Impressions from Jemdet Nasr and Ur. MSVO 2. Berlin: G. Mann.

McMahon, A. 2009. The Lion, the King and the Cage: Late Chalcolithic Iconography and Ideology in Northern Mesopotamia. Iraq 71: 115-124.

Monson, A., and Scheidel, W. (eds.) 2015. Fiscal Regimes and the Political Economy of Premodern States. Cambridge: Cambridge University Press. 
Nissen, H. J. 1986. The Archaic Texts from Uruk. World Archaeology 17 (3): $317-334$.

Nissen, H. J. 1993. The Early History of the Ancient Near East, 9000-2000 B.C. Chicago: Chicago University Press.

Nissen, H. J., Damerow, P., and Englund, R. K. 1993. Archaic Bookkeeping: Early Writing and Techniques of Economic Administration in the Ancient Near East. Chicago: Chicago University Press.

North, D. C., Wallis, J. J. and Weingast, B. R. 2009. Violence and Social Orders: A Conceptual Framework for Interpreting Recorded Human History. Cambridge: Cambridge University Press.

Polanyi, K. 2001. The Great Transformation: The Political and Economic Origins of Our Time. $2^{\text {nd }}$ Beacon Paperback edition. Boston: Beacon Press.

Pollock, S. 2001. The Uruk Period in Southern Mesopotamia. In Rothman, M. S. (ed.), Uruk Mesopotamia and its Neighbors: Cross-Cultural Interactions in the Era of State Formation (pp. 181-231). Santa Fe: School of Amerian Research Press.

Pomponio, F., Visicato, G., and Alberti, A.1994. Early Dynastic Administrative Tablets of Šruppak. Napoli: Istituto universitario orientale.

Porter, A. 2012. Mobile Pastoralism and the Formation of Near Eastern Civilizations: Weaving Together Society. Cambridge: Cambridge University Press.

Postgate, J. N.1986. The Transition from Uruk to Early Dynastic: Continuities and Discontinuities in the Record of Settlement. In Finkbeiner, U. and Röllig, W. (eds.), Gamdat Nasr: Period or Regional Style? (pp. 90-106). Wiesbaden.

Postgate, J. N. 1994a. Early Mesopotamia: Society and Economy at the Dawn of History. London: Routledge.

Postgate, J. N. 1994b. In Search of the First Empires. Bulletin of the American Schools of Oriental Research 293: 1-13.

Postgate, J. N. 2003. Learning the Lessons of the Future: Trade in Prehistory through a Historian's Lens. Bibliotheca Orientalis 60: 5-25.

Postgate, J. N. 2005. New Angles on Early Writing (Review of Jean-Jacques Glassner. The Invention of Cuneiform: Writing in Sumer and Stephen D. Houston (ed.), The First Writing: Script Invention as History and Process. Cambridge Archaeological Journal 15 (2): 275-280.

Potts, D. T. 2009. Bevel-Rim Bowls and Bakeries: Evidence and Explanations from Iran and the Indo-Iranian Borderlands. Journal of Cuneiform Studies 61: $1-23$.

Pournelle, J. R. 2007. KLM to Corona: A Bird's-Eye View of Cultural Ecology and Early Mesopotamian Civilization. In Stone, E. C. (ed.), Settlement and Society: Essays Dedicated to Robert McCormick Adams (pp. 29-62). Los Angeles: UCLA Cotsen Institute of Archaeology.

Pournelle, J. R. 2013. Physical Geography. In Crawford, H. E. W. (ed.), The Sumerian World (pp. 13-32). The Routledge Worlds. London: Routledge. 
Redmond, E. M., and Spencer, Ch. S. 2012. Chiefdoms at the Threshold: The Competitive Origins of the Primary State. Journal of Anthropological Archaeology 31: 22-37.

Renfrew, C., and Cherry, J. F. (eds.) 1986. Peer Polity Interaction and SocioPolitical Change. Cambridge: Cambridge University Press.

Richardson, S. 2012. Early Mesopotamia: The Presumptive State. Past \& Present 215: 3-49.

Richardson, S. 2015. Building Larsa: Labor-Value, Scale and Scope-of-Economy in Ancient Mesopotamia. In Steinkeller P., and Hudson, M. (eds.), Labor in the Ancient World (pp. 234-328). The International Scholars Conference on Ancient Near Eastern Economies 5. Dresden: ISLET-Verlag.

Rost, S. 2011. Irrigation Management in the Ur III Period: A Reconstruction based on a Case Study of the Maintenance of the íd-NINA-šè-du Canal of the Province Lagaš. Selz, G. J.and Wagensonner, K. (eds.), The Empirical Dimension of Ancient Near Eastern Studies (pp. 211-270). Wiener Offene Orientalistik 6. Wien: LIT Verlag.

Sallaberger, W. 2013. The Management of Royal Treasure: Palace Archives and Palatial Economy in the Ancient Near East. In Hill, J. A., Jones, P., and Morales, A. J. (eds.), Experiencing Power, Generating Authority: Cosmos, Politics, and the Ideology of Kingship in Ancient Egypt and Mesopotamia (pp. 219-255). Philadelphia: University of Pennsylvania Press.

Schloen, J. D. 2001. The House of the Father as Fact and Symbol: Patrimonialism in Ugarit and the Ancient Near East. Studies in the Archaeology and History of the Levant 2. Winona Lake: Eisenbrauns.

Schmandt-Besserat, D. 1996. How Writing Came About. Austin: University of Texas Press.

Schrakamp, I. 2013. Die Sumerische Tempelstadt heute: Die sozioökonomische Rolle eines Tempels in frühdynastischer Zeit. In Kaniuth, K., Löhnert, A., Miller, J. L., Otto, A., Roaf, M., and Sallaberger, W. (eds.), Tempel im Alten Orient (pp. 445-466). Colloquien der Deutschen Orient-Gesellschaft 7. Wiesbaden: Harrassowitz Verlag.

Scott, J. C. 1998. Seeing Like a State: How Certain Schemes to Improve the Human Condition have Failed. New Haven: Yale University Press.

Seri, A. 2005. Local Power in Old Babylonian Mesopotamia. London: Equinox.

Service, Elman R. 1978. Classical and Modern Theories of the Origins of Government. Cohen, R., and Service, E. R. (eds.), Origins of the State: The Anthropology of Political Evolution (pp. 21-34). Philadelphia: Institute for the Study of Human Issues.

Sherratt, A. 2004 Environmental Change: The Evolution of Mesopotamia. Published by ArchAtlas Version 4.1, cited 11 July 2015. Available from http://www.archatlas.org/EnvironmentalChange/EnvironmentalChange.php.

Skocpol, T. 1985. Bringing the State Back In: Strategies of Analysis in Current Research. In Evans, P. B., Rueschemeyer, D., and Skocpol, T. (eds.), Bringing the State Back In (pp. 3-37). Cambridge: Cambridge University Press. 
Smail, D. L. 2005. In the Grip of Sacred History. American Historical Review 110 (5): 1337-1361.

Smail, D. L., and Shryock, A. 2013. History and the 'Pre'. American Historical Review 118: 1-29.

Smith, A. T. 2003. The Political Landscape: Constellations of Authority in Early Complex Polities. Los Angeles: University of California Press.

Steible, H., and Yildiz F. 1993. Ki'enki aus Sicht von Šuruppak: eine frühdynastische Regio nach Fara-zeitlichen Urkunden. Istanbuler Mitteilungen 43: $17-26$.

Stein, G. 1999. Rethinking World Systems: Diasporas, Colonies, and Interaction in Uruk Mesopotamia. Tucson: University of Arizona Press.

Stein, G. 2005. 'Invisible' Social Sectors in Early Mesopotamian State Societies. In Scarborough, V. L. (eds.), A Catalyst for Ideas: Anthropological Archaeology and the Legacy of Douglas W. Schwartz (pp. 121-148). Santa Fe: School of American Research.

Stein, G. 2014. Economic Dominance, Conquest, or Interaction among Equals? Theoretical Models for Understanding Culture Contact in Early Near Eastern Complex Societies. In Hossein, M., Kharanaghi, A., Khanipour, M., and Naseri, R. (eds.), Proceedings of the International Congress of Young Archaeologists (pp. 55-67). Tehran: Archaeological Scientific Association.

Stein, G., and Özbal, R. 2007. A Tale of Two oikumenai: Variatian in the Expansionary Dynamics of 'Ubaid and Uruk Mesopotamia. In Stone, E. C. (ed.), Settlement and Society: Essays Dedicated to Robert McCormick Adams (pp. 329-342). Los Angeles: Costen Institute of Archaeology, University of California, Los Angeles.

Steinkeller, P. 1993. Early Political Development in Mesopotamia and the Origins of the Sargonic Empire. In Liverani, M. (ed.), Akkad: The First World Empire (pp. 107-129). Padova: Sargon.

Steinkeller, P. 2002. Archaic City Seals and the Question of Early Babylonian Unity. In Tzvi Abusch (ed.), Riches Hidden in Secret Places: Ancient Near Eastern Studies in Memory of Thorkild Jacobsen (pp. 247-257). Winona Lake: Eisenbrauns.

Steinkeller, P. 2004. Toward a Definition of Private Economic Activity in Third Millennium Babylonia. Rollinger, R., and Ulf, Ch. Monetary Systems in the Ancient World: Means of Transmission and Cultural Interaction, Oriens et Occidens (pp. 91-111). Studien zu antiken Kulturkontakten und ihrem Nachleben 6. Stuttgart: Franz Steiner.

Steinkeller, P. 2013 An Archaic 'Prisoner Plaque' from Kiš. Revue d'assyriologie et d'archéologie orientale 107: 131-157.

Tilly, C. 1985. War Making and State Making as Organized Crime. In Evans, P. B., Rueschemeyer, D., and Skocpol, T. (eds.), Bringing the State Back In (pp. 169187). Cambridge: Cambridge University Press.

Trigger, B. G. 2003. Understanding Early Civilizations: A Comparative Study. Cambridge: Cambridge University Press. 
Ur, Jason A. 2010a. Cycles of Civilization in Northern Mesopotamia, 4400-2000 B.C. Journal of Archaeological Research 18 (4): 387-431.

Ur, Jason A. 2010b. Urbanism and Cultural Landscape in Northeastern Syria: The Tell Hamoukar Survey, 1999-2001. Oriental Institute Publications 137. Chicago: The Oriental Institute.

Ur, Jason A. 2012. Southern Mesopotamia. In Potts, D. T. A Companion to the Archaeology of the Ancient Near East (pp. 533-555). Blackwell Companions to the Ancient World. Oxford: Wiley-Blackwell.

Ur, Jason A. 2014. Households and the Emergence of Cities in Ancient Mesopotamia. Cambridge Archaeological Journal 24 (2): 249-268.

van de Mieroop, M. 2002. In Search of Prestige: Foreign Contacts and the Rise of an Elite in Early Dynastic Babylonia. In Ehrenberg, E. (ed.), Leaving No Stone Unturned: Essays on the Ancient Near East and Egypt in Honor of Donald P. Hansen (pp. 125-137). Winona Lake: Eisenbrauns.

van de Mieroop, M. 2007. A History of the Ancient Near East, ca. 3000-323 B.C. Blackwell History of the Ancient World. 2 ed. Oxford: Blackwell.

von Dassow, E. 2012. Temporality and Periodization in Ancient Near Eastern History. Social Science History 36 (1): 113-143.

Wang, H. 2014. Writing and the Ancient State: Early China in Comparative Perspective. Cambridge: Cambridge University Press.

Wang, X. 2011. The Metamorphosis of Enlil in Early Mesopotamia. Alter Orient und Altes Testament 385. Münster: Ugarit-Verlag.

Wang, X. 2015. Mesopotamian Temples before the Sumerian Temple City. Paper read at International Conference Dedicated to the Centenary of I. M. Diakonoff, St. Petersberg: The State Hermitage Museum and the Institute of Oriental Manuscripts of the Russian Academy of Sciences.

Westenholz, A. 1999. The Old Akkadian Period: History and Culture. In Sallaberger, W., and Westenholz, A. (eds.), Mesopotamien: Akkade-Zeit und Ur III Zeit (pp. 7-117). Orbis Biblicus et Orientalis 160/3. Fribourg: Editions Universitaires.

Westenholz, A. 2002. The Sumerian City-State. In Hansen M. H. (ed.), A Comparative Study of Six City-State Cultures: An Investigation Conducted by the Copenhagen Polis Centre (pp. 23-42). Copenhagen.

Wittfogel, K. A. 1957. Oriental Despotism: A Comparative Study of Total Power. New Haven: Yale University Press.

Woods, C. E. 2010. The Earliest Mesopotamian Writing. In Woods, C. (ed.), Visible Language: Inventions of Writing in the Ancient Middle East and Beyond (pp. 33-84). Chicago: The Oriental Institute of the University of Chicago.

Wright, H. T. 1977. Recent Research on the Origin of the State. Annual Review of Anthropology 6: 379-397.

Wright, H. T. 1984. Prestate Political Formations. Earle, T. (ed.), On the Evolution of Complex Societies: Essays in Honor of Harry Hoijer (pp. 41-77). Malibu: Undena. 
216 Social Evolution \& History / March 2019

Wright, H. T. 2005. The Polycentricity of the Archaic Civilizations. In Scarborough, V. L. (ed.), A Catalyst for Ideas: Anthropological Archaeology and the Legacy of Douglas W. Schwartz (pp. 149-168). Santa Fe: School of American Research.

Wright, H. T. 2006. Early State Dynamics as Political Experiment. Journal of Anthropological Research 62 (3): 305-319.

Wright, H. T. 2007. Ancient Agency: Using Models of Intentionality to Unterstand the Dawn of Despotism. In Stone, E. C. Settlement and Society: Essays Dedicated to Robert McCormick Adams (pp. 173-184). Los Angeles: Cotsen Institure of Archaeology.

Wright, H. T., and Johnson, G. A. 1975. Population, Exchange, and Early State Formation in Southwestern Iran. American Anthropologist 77: 267-289.

Yoffee, N. 2001. The Evolution of Simplicity (Scott's Seeing Like a State). Current Anthropology 42 (5): 767-769.

Yoffee, N. 2005. Myths of the Archaic States: Evolution of the Earliest Cities, States, and Civilizations. Cambridge: Cambridge University Press.

Zettler, R. L., and Horne, L.(eds.) 1998. Treasures from the Royal Tombs of Ur. Philadelphia: The University Museum. 